\title{
The Oeuvre of Peter van der Veer
}

\author{
Irfan Ahmad
}

In lyrical appreciation of works by Peter van der Veer, my guru-ustād!

\section{Introduction}

The principal objective of the opening chapter to this volume is to present a critical assessment of the diverse writings, spanning three decades or so, of Peter van der Veer, a well-known Dutch anthropologist and arguably one of the foremost scholars of the comparative study of religion, nationalism and urban anthropology (unichicago.edu 2019). ${ }^{1}$ In order to undertake this task, I begin with a brief personal note in acknowledgement of the fact that the biographical and the academic are connected, at least in part.

In 2000, only two weeks after I was awarded a scholarship by the University of Amsterdam to begin my doctorate, I was granted another one, a Government of India Commonwealth scholarship. For a while, I

\footnotetext{
I. Ahmad ( $ه)$

Department of Sociology, Ibn Haldun University, Istanbul, Turkey e-mail: irfan.ahmad@ihu.edu.tr 
was in somewhat of a fix about whether I should go to the UK or Amsterdam. I chose Amsterdam, one key reason being Peter van der Veer's book Religious Nationalism. As an MPhil student at Jawaharlal Nehru University, New Delhi, I had read a photocopy of it. I liked it on three counts. Besides being relevant to what I wanted to do, it contained some hard truths about nationalism, particularly Indian nationalism. At that time-recall that Hindutva activists in league with state agencies had illegally destroyed the Babri Masjid in 1992 and that in its wake Muslims were living in a state of fear-'secular' critiques of Hindu nationalism or Hindutva relied on reviving Nehru's and Gandhi's ideals as an alternative to and in opposition to Hindutva. This approach was evident, inter alia, in books like Making India Hindu (Ludden 1996). In contrast, van der Veer argued that 'so much of the culture of the Indian state is already Hindu, in its "pluralist" version' (1994a: 31, 94, 23). In some ways, van der Veer anticipated Masuzawa's (2005) argument by over a decade. While Masuzawa argued that the invention of 'world religions' was a way to preserve European-Christian universalism, van der Veer argued that the orientalist-mediated reading of Hinduism as a 'universal religion' included Islam only through its exclusion, as it stigmatized Islam as an unwanted particularity. Similarly, for van der Veer, Gandhi's ideas were not an effective antidote to Hindutva, as they were themselves a 'moderate' version of Hindu nationalism (I return to this later). Nehruvian secularism was likewise complicit, as was evident in its lack of action against those who, in 1949, had illegally installed Hindu idols inside the Babri Masjid or when in 1950 the 'secular' state backed construction of the Somnath temple project (1994a: 155-157, 146-152).

Second, the book appealed to me because of its grasp of theory, absent, for instance, from Jaffrelot's (1996) otherwise voluminous book on the same topic. In addition to criticizing Benedict Anderson, Ernest Gellner and others, it also questioned the 'derivative discourse' thesis. Van der Veer argued that 'Indian nationalist politics is to a significant degree "indigenous" (1994a: 20), a point later acknowledged by the political theorist Bhikhu Parekh (2019: 246).

Third, its exposition of Islam-a subject I was interested in-was significantly different from that in other works, which either simply erased Muslims (e.g., Chatterjee 1986; on which see Ahmad 2017; Hasan 1998) 
or, if they discussed them at all, did so patronizingly. Before I began my doctoral studies at the University of Amsterdam, my knowledge of British academia was limited, if not poor. I was familiar with the historian Francis Robinson's work, but he did not have much to say about 'postcolonial' India. I was also familiar with the works of Sudipta Kaviraj, then based at the School of Oriental and African Studies, University of London, and was in touch with him. He is a political scientist, not a specialist in Islam. The challenging journey of my MPhil research on a Muslim movement and the decision to continue to do research on Islam for my $\mathrm{PhD}$ made me readily appreciate the worth of terse sentences in Religious Nationalism such as these: 'anthropologists want to make a contribution to the understanding of what is understood to be the "dominant culture" of the majority. They thereby unwittingly support Hindu nationalism' (1994a: 196). I also felt a sense of the scholarly isolation that van der Veer later articulated so tellingly: 'students of Indian Islam almost form a separate community ... reflecting the separateness of the community they study, almost implicitly acknowledging that Muslims do not "belong" to India' (2008: 385). ${ }^{2}$

From this personal note, let me now switch to an overview of van der Veer's works, at the analytical core of which is the triad of Western modernity, its relations with contemporary non-Western countries (especially India and China) over the longue durée and the subject of religious and cultural diversity. Put differently, his scholarship is mostly an investigation of the interrelationships between modernity's political form-the nation-state - and religion, in which the latter, until recently, was treated as no more than a residue of the past. Van der Veer's scholarship broadly falls into two different, yet overlapping phases: from 1985 to 1994, and from 1995 right up to the present day, which is continuing productively (e.g., Meyer and van der Veer 2021). While each phase has some distinct features that I will shortly discuss, there is also a commonality across them. There are three aspects to this commonality: comparative, historical and empirical, all marked by combative modes of theorizing. I use 'combative' in the sense of Talal Asad (in Scott 2006: 247-249). All these elements bear the mark of van der Veer's engagement with philosophy: now secret, now public. Derrida's remark that 'Bourdieu relates to philosophy as a man relates to his mistress' ${ }^{3}$ (in Hage 2013: 79) seems 
pertinent here. Whether engaging with Hegel, Marx, James Mill, Charles Taylor, Habermas, Rawls or Seyla Benhabib (van der Veer 2016: 73-79, 2001a: 3-11, van der Veer and Lehmann 1999: 3ff.), van der Veer is both philosophical and anti-philosophical. With eyes cast on the ground and his mind in a quest to grasp the larger picture, he is against the supposed universality and 'generalism' of philosophers and the 'endless particularity' informed by the British-style inductive empiricism that is evident in many works, including anthropological ones (2016: 148). His mode of intervention is often persuasively combative.

The rest of this chapter is divided into three parts. In the first part, I dwell on van der Veer's early works from 1985 to 1994, which deal largely with South Asia. Here I discuss his contributions to the study of Hinduism, orientalism and nationalism. Part two is devoted to an analysis of his works during the second phase from 1995 to the present (2016 to be precise). Though diverse, I have organized my critical analysis of these works under the overarching category of comparison. The final brief section aims to identify the style and mode of van der Veer's interventions, the sine qua non of which I describe as 'theorization with a hammer'. On occasions, I draw on the personal to elucidate certain points.

\section{Hinduism, Orientalism, Nationalism: 1985-1994}

The first of van der Veer's combats was directed against orientalism as both a field of inquiry and a method. This is most obvious in van der Veer's doctoral monograph, Gods on Earth (1988), described by Nita Kumar (1990: 583) in American Ethnologist as 'an exceptionally valuable and enjoyable book'. Based on long-term ethnographic fieldwork (from 1977 onwards) in Ayodhya, a famous Hindu pilgrimage centre believed to be the birthplace of the god Ram, himself considered an incarnation of Vishnu, and supplemented with archival research, it was a powerful critique of Indology as a field. Indology then dominated the study of Hinduism, and anthropologists such as Jonathan Parry also subscribed to this argument (van der Veer 1985: 306), if differently. In some ways, Gods 
on Earth was probably a critique of van der Veer himself or more accurately of his earlier pre-anthropological training as a Sanskritist and Indologist at the University of Groningen in the Netherlands (1988: vii). ${ }^{4}$ Focused on the Rāmānandī order, the Hindu specialists of priests and monks who lived in Ayodhya, rather than the transitory hundreds of thousands of pilgrims who visited the town, its main problématique was the formation of the identity of these Hindu specialists. Contrary to his predecessors and many contemporaries who privileged Hindu values in their analyses, van der Veer looked instead at their contextual actions and practices. In place of eternal values read through the lens of and enshrined in sacred texts, he urged scholars to take priests as political actors who both shaped and were shaped by larger historical processes of economy and state formation. The relations among the Hindu priests and monks were marked by serious competition, even conflicts. Against popular perceptions of sadhus as a category of spiritual specialist disinterested in society or unmusical about politics, van der Veer found that they acted like businessmen. Furthermore, they were not unsullied emblems of nonviolence. Rather, unlike Tyāgīs and Rasiks, the subgroup of Nāgās among the Rāmānandīs indeed believed in violence and was also trained in fighting.

The journal articles from his doctoral research (e.g., van der Veer 1985, 1987) criticized specific Indologists without using the term 'orientalism', as Gods on Earth was to do. For van der Veer, orientalism was responsible for the prevailing portrait of Hindu society as 'static, timeless' and as 'dominated by Brahmans as guardians of the sacred order of society'. After World War II, when anthropologists shifted their attention away from tribes living on the frontiers of Hindu civilization to studying caste/ Hindu villages, they too contributed to the orientalist portrait. The synchronic study of villages by anthropologists such as Robert Redfield and Milton Singer operated on the binary premise of the Great versus Little Traditions, the former enshrined in Sanskrit literature and spatially anchored in 'sacred centres', the latter found in villages as forms of deviation from the former (McKim Marriot called it parochialization as opposed to the obverse process of universalization). Louis Dumont and his collaborator David Pocock consolidated this line of inquiry by announcing, in 1957, that a proper sociology of India must combine 
sociology and 'classical Indology'. For Dumont, classical Indology was so foundational that he saw no difference between the religious and the social because 'all that appears to be social is in fact religious'. Drawing on Talal Asad's (1993) critique of Clifford Geertz, van der Veer argued that orientalists in general, and the anthropologist Dumont in particular, failed to account for the shifting relations between meaning and power. In so doing, they unduly privileged the self-perceptions of the Brahmans. Describing this approach as distinctly theological, he considered it 'detrimental to anthropological research'. Hence the call to free the 'anthropological study of Hinduism' from 'the orientalist perspective with the intellectual and theological overtones that have dominated it from the start' (van der Veer 1988: 55, 57, 58).

Five years after issuing this call, however, van der Veer had discovered that it was not that easy to free the anthropological study of Hinduism and India from orientalism. The volume Orientalism and the Post-colonial Predicament, co-edited with Carol Breckenridge, synoptically expressed this dilemma by using the word 'predicament' in its title. Its main aim, as set out in the Introduction, was to examine the 'relations between colonialism and nationalism in the politics of culture in both the societies of the ex-colonizers and those of the ex-colonized'. For Breckenridge and van der Veer, postcolonial nationalism can hardly avoid orientalism, the intellectual-cum-scholarly wing of colonialism. Building on Edward Said's (1995 [1978]) work while also criticizing it, they extended the scope of the debate from the Middle East, the prime focus of Said's study, to South Asia. The extension was also thematic, from literary works to administrative catalogues and practices within the social sciences. ${ }^{5}$ Unlike Said's voyage, which took him largely into history, Breckenridge and van der Veer were interested instead in the postcolonial South Asia of the present, where they saw 'significant continuities' between colonialism and postcolonial nationalism. Their basic criticism of Said was that 'colonized subjects are not passively produced by hegemonic projects but are active agents ... in the formation of their societies'. Moreover, orientalism informs the Orient as much as the Occident. The postcolonial predicament regarding orientalism was evident in the fact that the methodologies and theories used by postcolonial subjects themselves had emerged during the colonial era. Postcolonial nationalism and 
decolonization therefore cannot 'escape from a history characterized by a particular discursive formation that can be called "orientalism" (Breckenridge and van der Veer 1993: 1, 4, 5, 2).

Van der Veer's own chapter in the volume-'The Foreign Hand: Orientalist Discourse in Sociology and Communalism'-contained a systematic analysis of Dumont's scholarship on India, especially his famous essay on nationalism and communalism (Dumont 1970). In it, van der Veer argued that 'Indian nationalism undoubtedly is an anticolonial force, but in its very anticolonialism, it shares basic discursive premises with orientalism and with the nationalism of the colonizing British'. Far from being antagonistic to each other, he went on to say that Gandhi's discourse and the postcolonial Hindu militant discourse 'present variants of Hindu nationalism'. As a discipline, anthropology did not stand outside these historically constituted relationships between knowledge and power. Rather, there were 'fascinating convergences' between orientalism, Hindu nationalism and sociologies such as Dumont's. Van der Veer also connected his argument to the then emerging subject of transnationalism, dwelling chiefly on the transnational movement of Vishva Hindu Parishad or VHP (see van der Veer 1994b, 1987), to conclude that 'it is the postcolonial predicament that orientalism is reinvented in the dialectic of nationalism and transnationalism' (van der Veer 1993: 39, 40, $41,43)^{6}$

Van der Veer did not limit his critique of orientalism to South Asian contexts: he also brought it back home, as it were. In his 1995 book on orientalism, written in Dutch (van der Veer 1995), he undertook a critique of Christiaan Snouck Hurgronje (1857-1936), the internationally renowned Dutch orientalist who was Professor of Islam and the chairperson of the Koninklijk Instituut voor Taal-, Land- en Volkenkunde (KITLV, or Royal Institute of Linguistics, Geography and Anthropology) in Leiden. Maarten Kuitenbrouwer's book on the KITLV, published to mark its 150th anniversary and sympathetic to Hurgronje and his tradition, described van der Veer as having targeted Hurgronje and 'assailed Leiden Indologists past and present with Said's contention'. To place this issue in perspective, the Dutch Ministry of the Colonies had financed Hurgronje's trip to Arabia to make inquiries among Indonesian pilgrims to Mecca. Later, the Dutch state used Hurgronje's knowledge in the 
bloody military assault of 1898 on Aceh, which killed over 50,000 people out of a population of about 500,000 (van der Veer 2002a, 2004b; 2010 : 215 ). In Kuitenbrouwer's account, van der Veer, 'the Amsterdam scholar of religious sociology', viewed Hurgronje as an imperialist and drew an analogy between Dutch colonialism in Indonesia and the Nazi occupation of the Netherlands. Responses to van der Veer's critique like Kuitenbrouwer's were largely acrimonious, if not unscholarly. While in a newspaper column the historian H.L. Wesseling condemned 'the Amsterdam sociologist' for what he called 'modern stupidity', for H.W. van den Doel no amount of criticism of Hurgronje could dislodge the fact that the latter was 'the radiant sun in the Leiden universe' (in Kuitenbrouwer 2014: 72, 8). ${ }^{8}$ If the responses to van der Veer's critique in this case were less than civil and academic, in another case van der Veer received an unexpectedly reasoned response, approximating as it did to the notion of critical academic discussion. In publications resulting from his doctoral fieldwork, he had immanently criticized the works of Jonathan Parry and Chris Fuller, both at the London School of Economics (LSE). On publication of his critique, and exemplifying the British idea of 'fair play', he received an invitation to become a visiting scholar at the LSE (van der Veer 2008: 378). ${ }^{\text {? }}$

Returning to the subject of the interconnections between nationalism and orientalism, the volume van der Veer co-edited with Breckenridge (mentioned earlier) foregrounded but fell short of offering a full-scale treatment of the former, logically suggesting that an examination of nationalism in its own right was overdue. This precisely became van der Veer's goal in Religious Nationalism, published in 1994, one year after Orientalism and the Post-colonial Predicament. As I have already discussed aspects of Religious Nationalism in the Introduction, here I will mention some additional features of it I regard as salient.

Focused on Hindu traditions, Gods on Earth too was a comparative work, if diagonal in nature. The comparison in Religious Nationalism, by contrast, was across religious traditions-Hindu, Muslim, Sikh. The academic community received it with much enthusiasm and applause. While the Journal of Asian Studies (McKean 1994: 1309) praised it as 'an appealing book' on account of the 'clarity of its argument, the breadth of its dialogue with other works on nationalism, and its informative range of 
ethnographic and historical materials', Man described it as a 'challenge' to 'the received wisdom' (Fuller 1994: 1025). According to Brian Smith (1997: 164), a scholar of comparative religion, it offered 'the best and most sophisticated analysis to date' of religion and nationalism and as such was a 'definitive work'. At its core, the book offered a resounding critique of modernization theory, which, based on the Enlightenment premise, suggested a correlation between secularism and nationalism. Benedict Anderson's and Ernest Gellner's works displayed this secularist assumption in their conceptualizations of nationalism. For Gellner, by erasing the particularities of tradition industrialization produces homogenization, which in turn leads to individualization and nationalism, both of which he viewed as far removed from religion. In Anderson's analytical scheme, nationalism marks a rupture with the traditional realms of the religious community and the dynasty that preceded it. In contrast, van der Veer argued that the religiously diverse case of India showed the continuing significance of religion in nationalist discourses and practices, past and present. The pervasive role of religion, however, did not mean that religion was a timeless idea but a practice constituting and constituted by modernity. To demonstrate this thesis, he focused on sacred centres, networks of religious specialists (Hindu saints, Muslim Sufis and reformers), religious rituals (see Fig. 2.1) and their modes of communication in Hindi and Urdu, competing notions of self and other, imaginations of territory and the like. In sum, the book called the modernization paradigm into question, urging scholars to pay attention to the power of religion beyond 'the master narrative of European modernity' (1994a: 202).

Was the Indian phenomenon of religious nationalism unique, however, or could it be compared with other cases elsewhere, including in Europe? The stage was set for a comparison different from that van der Veer had undertaken in Religious Nationalism. Co-edited with Hartmut Lehmann, Nation and Religion ${ }^{10}$ compared Asia and Europe by discussing the intertwining of religion and nation in India, Japan, the Netherlands, the Middle East (partly) and the UK. Anderson, in its short final chapter, defended his earlier argument.

Beyond the liberal obsession with volition and choice, however, the decision to undertake this comparison was not entirely van der Veer's 


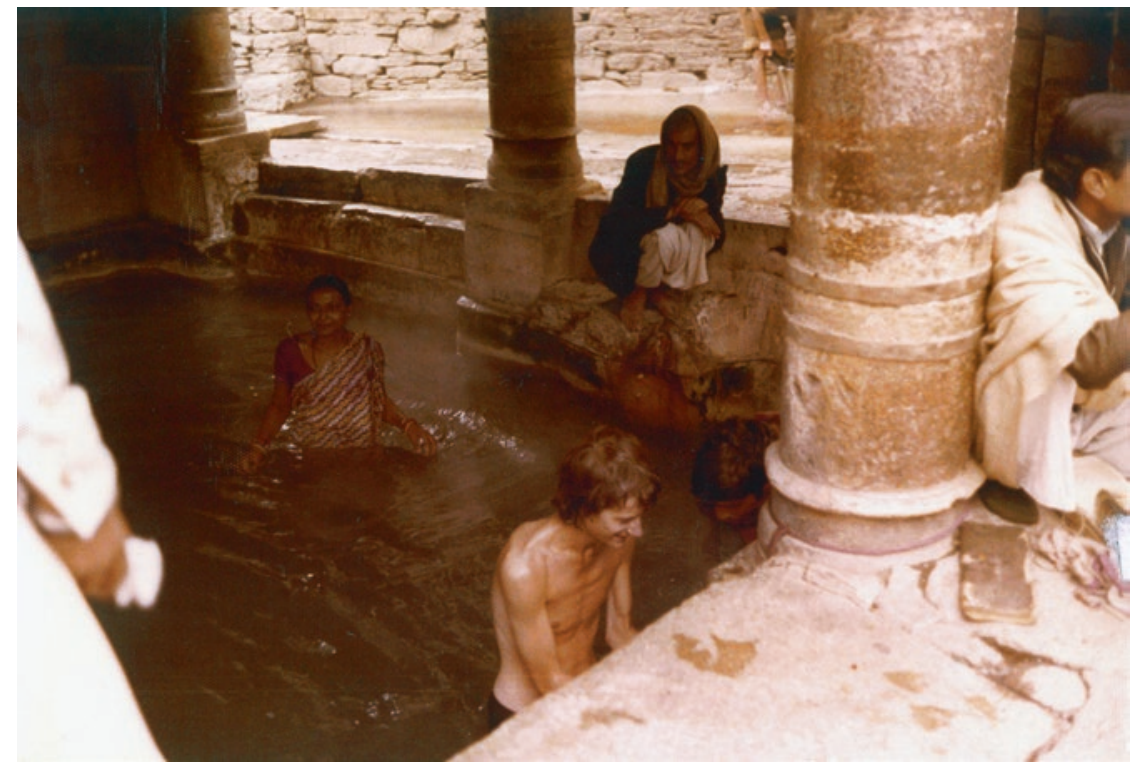

Fig. 2.1 Peter van der Veer taking a ritual bath on the pilgrimage route to the temple of Kedarnath, India, 1980

own. After researching Hindu social-political formations, he wanted to turn to Indian Muslims. Against the common perception, shared also by the 'liberal-secular' intelligentsia, van der Veer considered Islam an 'Indian religion' on which he had also begun his fieldwork in Surat (see van der Veer 1992), a city in the western state of Gujarat from where India's current prime minister, Narendra Modi, hails. However, the Indian government did not grant him permission to conduct fieldwork there. The large-scale anti-Muslim violence in Surat after the destruction of the Babri Masjid in 1992 made any such research plan impossible (van der Veer 2008: 385). From the early 2000s, van der Veer's interests shifted to China and its vicinity. Despite friendly warnings that it was too late for him to begin to study a new language and culture, he started learning Mandarin (van der Veer 2014: ix-x). Such was his determination! In many important ways, this determination inaugurates (non-monodirectionally) the second phase of van der Veer's academic life. 


\section{Comparison Past the Enlightenment Hubris: 1995 to the Present}

If there is a single theme that undergirds van der Veer's work from 1995 onwards in a variety of ways, in my view it is comparison. His work from this point on becomes a multifarious exercise in enunciating, clarifying, refining and demonstrating what comparison, normally taken as a truism by anthropologists and others, means or should mean for our times. Eschewing the demotic notion of comparison as a method, in what follows I will discuss the conceptual and theoretical underpinnings of van der Veer's idea of comparison, culminating as it did in The Value of Comparison (2016). Delivered first as the prestigious Lewis Henry Morgan Lecture for 2013, in some ways the resulting book may be considered a summative manifesto of some of his many works of significance during this phase.

One way to understand the subject of comparison is to begin with an outline of its general parameters. Though an exponent of the longue durée approach in history, unlike Fernand Braudel, for whom it may mean several centuries, or even a millennium (Ahmad and Kanungo 2019), in practice for van der Veer it means a shorter and evidentially more plausible time span linking the eighteenth century to the present. Notwithstanding this difference, both Braudel (1980) and van der Veer share a refusal to be seduced by presentism (van der Veer 2014, 2011: 9). This history, for van der Veer, is 'interactional' as opposed to the prevalent form of nationalist historiography exemplified in 'little Englandism' on the one hand and 'big Indianism' on the other. That is, if Indian historiography is largely unmusical in respect of the impact of the colony on the metropole, English history posits Britain's immunity from influences from the colonies, the latter being assigned to the specialists of colonial history. By contrast, the task of interactional history, situated in the matrix of knowledge-power, is to reveal the entanglement of what are seen either as opposites or as not connected or as both. How is this specific interactional history different from global history and world-system perspectives on political economy frameworks practised, though not identically, by Andre Gunder Frank, Karl Marx, Sydney Mintz, Immanuel 
Wallerstein, Eric Wolf and others? While appreciative of many of the merits of such frameworks, van der Veer finds them deficient because they do not tell readers about 'the ways people shaped their understanding of these world historical processes'. Moreover, they privilege factors of economy and downplay the significance of culture and religion (van der Veer 2001a: 8-11, 2014: Ch.1, 2016: 17-18). The insistence on the valency of the social and cultural gains further significance because van der Veer, like Marshall Sahlins, rejects the focus in cognitive and evolutionary anthropology on, among other things, the so-called universalism of brain science (van der Veer 2016: 41ff.). ${ }^{11}$ However, van der Veer's discomfort with materialist frameworks does not lead him into a celebration of the 'culturalist approach' of, for example, Max Weber. ${ }^{12}$

In Imperial Encounter, which offers the most elaborate account of the notion of interactional history to be cast in a comparative frame, van der Veer's goal is fairly modest. In it, there is no claim to present 'an alternative history'; instead, it offers 'alternative ways to look at the familiar problems and materials' (van der Veer 2001a: 13). One of its principal objectives was to interrogate the opposition between the religious and the secular, in Britain and India alike. This inquiry is tracked through various sites, investigating the very concept of religion and its changing trajectory, the role of Hinduism in the making of the masculine Hindu man and the role of Christianity in the making of the masculine Englishman, the entailment of race, religion and nationalism, and so on. In The Modern Spirit of Asia, the goal, over a decade later, is noticeably bolder: 'What I offer in this book is a nonsecularist counter narrative'. The question of the secular-religious opposition unfolds differently here, as a 'syntagmatic chain of religion-magic-secularity-spirituality', where the four elements in the chain are interdependently located in relation to the state (van der Veer 2014: 9).

Along with the scale and temporal horizon, what to foreground as a unit of investigation is a much-debated issue in the literature on comparison. For van der Veer, the unit cannot be civilization as Max Weber posited it, as Weber's discourse compared 'civilizational essences' rather than 'historical networks' (van der Veer 2001a: 10). One may add that, as a sociologist of empire, Weber effaced empire as an important category in his analysis (Allen 2017). This Weberian preoccupation with essences, 
van der Veer justly observes, was predicated on an 'oriental deficiency' (2016: 66). Though he does not say as much, van der Veer's refusal to deploy the category of civilization also implies a critique of Norbert Elias (most explicitly, of Samuel Huntington, of course). A theorist of the civilizing process and Weberian in his orientation, Elias, in Jack Goody's view, was ethnocentric, as he took the civilizing process as unique to the history and sociology of the West (Goody 2002; cf., Liston and Mennell 2009, who defend Elias). Taking Elias's theory as biased, Goody showed how Elias made no systematic comparative investigation of the non-West. However, this did not prevent Elias from placing increasing self-restraint at the heart of his argument about the civilizing process, opposing it to the Naturvolk in Ghana.

If not civilization, what about the nation-state? Van der Veer categorically shuns this too as a viable unit of comparison. He pointed out that the emergence of the social sciences as academic disciplines in Europe coincided with forms of and thinking about the nation (2014: 9-10). Since anthropology was hardly an exception to this historical association, it pursued its research agendas in cahoots with the interests and aspirations of these states. Many anthropologists took the anthropological notion of holism as synonymous with society, which in turn had become substitutes for nation-states (Giddens 1990). This conception of society 'as a unified whole' led to 'the typecasting of societies and religions in a particular unifying way'. Especially revealing in this context is van der Veer's phrase 'the macro sociological form of ethnic profiling', which he uses to characterize holism-inspired works such as Patterns of Cultures by Ruth Benedict, The Cultural Background of Personality by Ralph Linton and similar works by Abraham Kardiner and Francis Hsu (van der Veer 2016: 31, 159n20). ${ }^{13}$

If neither civilization nor the nation-state is a viable unit of comparison because of the notion of a priori 'whole' on which both are predicated-whether as ideal types or as universal models-what is the alternative? Van der Veer's answer is 'fragment'. In my reading, however, the relations between the fragment that he strongly advocates and the whole that he wants to abandon for good are hazy, if not under-thought. One thought that comes to mind is this: fragment, fine-but which entity is the fragment part of, conceptually, relationally and spatially? 
Does the fragment have an existence of its own? Is not the fragment actually itself a whole kept in abeyance by a particular configuration of power? Setting these questions aside for the moment, the highly illustrative examples the book offers judiciously guide anthropologists and others on to the path of van der Veer's comparative project. An example of a comparison of fragments that arrested my attention in The Value of Comparison is the chapter on care and sanitation in relation to the subalternated. Using a historical lens, this chapter beautifully illuminates this subject by comparing China (see Fig. 2.2), India and the Netherlands. Equally revealing is the chapter that compares the issue of religious minorities, namely Muslims in India, China and Western Europe respectively-a comparison that is unusually rich as much as it is rare. Seen from the Indian nationalist perspective, it is almost defiant in that many Indians display their own brand of 'exceptionalism' in resisting any comparison

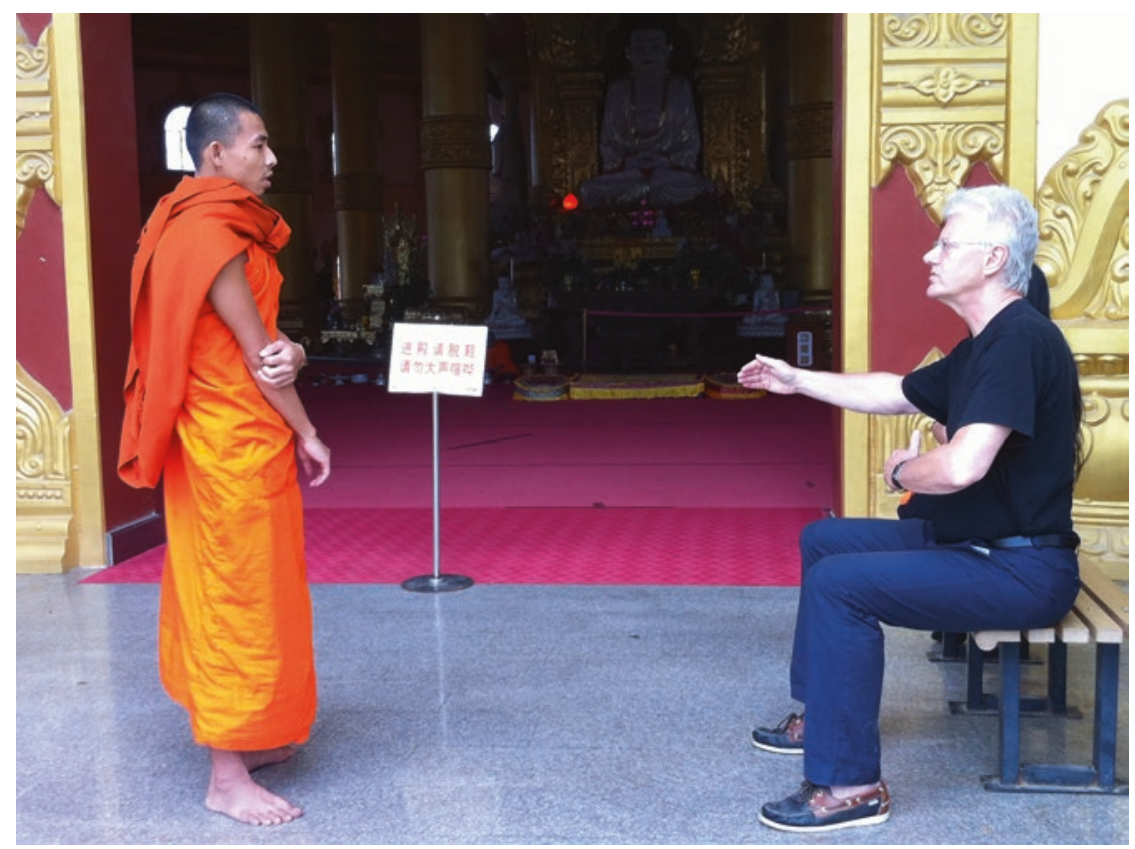

Fig. 2.2 Peter van der Veer interviewing a Burmese monk in Dehong, Yunnan, China, 2013 
between 'democratic' India and 'communist' China. ${ }^{14}$ Beyond the respective differences in their political arrangements, here van der Veer shows instead how the commonality of nationalism and its discourse promoting the idea of a unified nation threatened by 'others' permits a comparison of fragments between China, India and Europe.

In addition to showing us a new path of sustainable comparison, the contribution of The Value of Comparison, as I see it, is theoretical. More boldly and convincingly than other works, it questions the 'continuing Western ethnocentrism in research' that is derived from, as well as evident in, the modernization paradigm or the very concepts that are beholden to the Enlightenment and its postulates, whether they are, for example, democracy, tolerance, civil society, religion, the public sphere, secularism or the family. Though articulated more forcefully here, a healthy distrust of Western and Christian categories or categories derived from them is discernible as early as 1987, well before the publication of van der Veer's first monograph. In an article in Man, he disowned the prevalent use of the term 'sect' which scholars unproblematically applied to the Rāmānandi branch of Hindu monks (discussed earlier). Pointing out the origin of the term 'sect' in Europe as a breakaway group from the Church, he described Rāmānandīs as an order rather than a sect because the Church as an institution did not exist in Hinduism (1987: 683: ff.). By raising such conceptual questions, The Value of Comparison, in short, becomes a remarkable intervention, the task of which is nothing less than putting the regnant idea of 'the self-sufficient Euro-American modernity' (van der Veer 2016: $46,28)$ in its place. Early on, and by expanding the horizons of anthropology, the Introduction makes this clear. Below are some 'fragments':

Anthropology is primarily an engagement with 'difference' and 'diversity' and focuses on problems of cultural translation. As such, it offers a critique of the universalization of Western models and provides thus a basis for a comparative sociology. Ethnographical data derived from fieldwork form a big part of anthropology, but the study of other kinds of material—historical, textual, and visual-also benefits from an anthropological perspective.

Anthropology is the only social science that reflects on Western ethnocentrism and takes the problem of translation seriously. ${ }^{15}$ 
Comparison is thus not a relatively simple juxtaposition and comparison of two or more different societies but a complex reflection on the network of concepts that underlie our study of society as well as the formation of those societies themselves. It is always a double act of reflections. (van der Veer 2016: 9, 20, 29)

One should note, if parenthetically, the presence of the Netherlands, van der Veer's home nation-state, in the entire comparative enterprise. Certainly it was never a formal research site for him. However, its history, sociology and politics inform the comparative enterprise throughout, though not necessarily and overtly everywhere. Whether writing about secularism, tolerance or sanitation in India and China and placing them both in comparative relations to the West, the Netherlands serves as one among many points of reference (van der Veer 2006, 2016: chapter vi). I too came to learn the Dutch meaning of 'home' comparatively, though rather differently. In the very early months of my PhD, van der Veer arranged a reading session with me to make me think comparatively about my own research on India. My assignment was to read and discuss with him two works: Robert Hefner's Civil Islam: Muslims and Democratization in Indonesia (2000) and Robert Putnam's Making Democracy Work: Civic Traditions in Modern Italy (1994). After the session, I casually mentioned this to some of my fellow $\mathrm{PhD}$ friends. One of the responses I still remember was, 'He invited you to his home for the discussion?' For me, there was nothing surprising in this: many of my friends visited me in Patna, India, at my parents' home, a two-room firstfloor apartment where, if we had meals, we took them with newspapers or a tablecloth spread over my father's bed in the room close to the tiny balcony (there was no separate dining area). Home invitations in the Netherlands, by contrast, generally deny visitors access to the bedroom. It was hard to miss the comparative meanings of home in Patna and Utrecht. This observation contributed, partly, at least, to my formulation of the neologism of domophilia as a phenomenon relationally positioned to Islamophobia as a global phenomenon and going well beyond the distinctions between 'East' and 'West' or between democratic versus authoritarian and/or monarchical nation-states (Ahmad 2013). 


\section{On the Very Style, and a Little More}

At this point I will say a word or two about van der Veer's style of intervention as a prolific writer. In my opinion, it resembles Nietzsche's style: 'to philosophize with a hammer'. This phrase is the subtitle of Twilight of the Idols (see Brobjer 2010: 38). For the purposes of this chapter, let me rephrase it as 'theorizing with a hammer'. Often hastily yoked by his commentators to the vocabulary of warfare alone, Nietzsche's metaphor was an expression that is also constructive and diagnostic. Deborah Cook (2018) and Amy Allen (2016: 193-195) use it as a method of exaggeration and hyperbole- the objective of which is not to leave putative reality behind, but to underline the sheer value of a thought at its utter extreme, unclouded by excesses of ifs and buts. This method-or technique if you will - also informed the writings of Adorno and Foucault (the latter once told his interviewer that he had written nothing else but fiction) (see Cook 2018: 150n130).

In making arguments, many if not most anthropologists proceed with the utmost caution, especially if and when they engage with viewpoints they want to contest or position themselves against. 'Nuance', 'off the mark', 'over-stretched', 'one-sided', 'too watertight' and so on thus characterize their prose. Not van der Veer's, however. I do not mean that such words or expressions are entirely absent from his writings. What I suggest instead is that those writings also (and often) contain words like 'mistake', 'erroneous', 'misleading' and 'meaningless'. Having discussed Dumont's structuralist understanding of the Hindu caste system, without mincing his words, van der Veer wrote that to assume 'a structural opposition of asceticism versus devotionalism' is 'to commit a basic error' (van der Veer 1987: 693). Likewise, in criticizing Jonathan Parry's understanding of the position and role of Brahman priests, van der Veer wrote: 'In Parry's analysis ... the highest aim in life for the Brahman priest is to leave his priestly profession. ... I think this interpretation is erroneous' (1985: 319). To take another example, he criticized Edward Said as follows: 'It would be a serious mistake to deny agency to the colonized in our effort to show the force of colonial discourse' (van der Veer 1993: 23). About Anderson, van der Veer wrote: 'Such a misleading conception is 
also fundamental to Benedict Anderson's ground-breaking discussion of nationalism' (1994a: 15). One more example will suffice to demonstrate my point about van der Veer's theorization with a hammer: 'religion's organization, its place in society ... are so different in Japan that ... a simple form of the secularization theory ... derived from ... Western Christianity becomes meaningless' (van der Veer and Lehmann 1999: 10, all italics here the author's).

To conclude this short section, let me note another feature of van der Veer's scholarship. A reader of his works from the 1980s to the present will be struck by the fact that, while he has engaged extensively with new things, continuities of certain ideas, themes and authors mark his oeuvre. For instance, regardless of the change in fieldwork sites, relocation for reasons of employment from one country or continent to another, and movements in time, religion and modernity/the West, both broadly construed, have remained the pivot of his thinking. Thus viewed, globalization is not a process that is unhooked from religion, as economists and political scientists would have us believe, but a 'genre' of religion (van der Veer 2011: 9). As for authors and interlocutors, Arjun Appadurai, Talal Asad, Louis Dumont, Clifford Geertz, Marcel Mauss and Max Weber, among others, recur in his texts from the first monograph of 1988 through to the latest of 2016.

\section{In Lieu of a Conclusion}

Clearly, this chapter makes no claim to present an all-inclusive analysis of van der Veer's entire corpus of writings. Rather, it is one among many possible analyses — and a preliminary one at that. To be sure, the chapter bears the marks of my own research interests (hence its limitations). I do not have a precise conclusion to make. Given the format and aims of this chapter, that in fact seems less than desirable. In lieu of a conclusion, therefore, I will use this space to make some remarks about themes and questions that van der Veer's works do not squarely address but that gainfully work as analytical enablers of future research.

Judging from his publications, it is obvious that van der Veer is hardly an admirer of the nation-state as a political institution or of nationalism 
as a corporate ideology — the passion of which has much affinity with modern religion, itself considerably nationalized. He is equally sceptical of nationalism in its current, more popular garb of civilizationalism, put in place by Huntington and readily embraced by such International Relations theorists such as Peter Katzenstein, who characterizes China, India and the US as civilizational states (van der Veer 2016: 64). One can sense this discomfort being splashed throughout many of his writings, often not directly enough. However, one does not see any full-blown theorization of the pre-, non- or anti-national forms of life (intertwined with death) as alternative, parallel or counter to the nation-state, much less post-national belonging (on which, see Appadurai 1996), which is surely hegemonic, even naturalized, though the history of it, and probably the future too, is soaked in blood. It is true that from the eighteenth century an ascendant Europe significantly transformed much of the nonWestern world by mapping it along the axis of nationalism, and eventually in the institutionalized forms of the emerging nation-states. No less true, however, is the presence of counter-imaginations, in West and nonWest alike, to the hegemonic projects of nation-states. Writing about French West Africa, Fredrick Cooper $(2011,2018)$ observes how, during the 1930s and 1940s, many intellectuals and politicians there, as well as those in France, nursed and worked for political programmes that cannot be reduced to forms of or thinking about the nation. In India, Hasrat Mohani (1878-1951), an important anti-colonial leader and journalist, viewed the future free India as a 'Constitutional Indian Union of Federations of Republics'. He visualized one federation each in the east, south, centre, south-west, and west of India, each federation in turn comprising many republics organized along regional and/or linguistic lines (in Ahmad 2015: 103). Clearly, there was hardly any enthusiasm for Mohani's vision, certainly not among the ethnic partisans of muscular Indian-cum-Hindu nationalism, and today most Indians do not even know his name. The absence of enthusiasm for Mohani's ideas and the utter lack of knowledge of him among contemporary Indians should not astonish us. Given its anti-doxa force, Mohani's proposal looked confusing and disturbing to the partisans of nationalism. This by no means diminishes the radical import of non-national forms of thought in West Africa or India. The point is to recognize that nationalism or nation-state 
thinking was not the only thought available. We should also note that states like Syria were created not in consonance with the 'national' wishes of its people but in 'defiant opposition to the vast majority' (Farouk-Alli 2014: 8). In short, and especially because of the world-wide rise of populism (on which see Ahmad 2019a), the significance of an accomplished comparativist like van der Veer investigating non-national forms of life need not be stressed. In a review of Eric Wolf's famous book, Europe and the People without History, Asad (1987) asked: 'are there histories of people without Europe?' To pursue such questions, one may ask: Are there histories of non-, anti- or counter-nationalism within and without Europe? If so, do they have any future-immediate, postponed, delayed, interrupted or denied (see the Introduction, this volume)?

As for religion, which along with the nation-state has been van der Veer's life-long concern, in a recent interview with the Times Higher Education Supplement (Matthews 2018), he observed that the Netherlands of his childhood was so religious that one's whole life was organized along lines of religious affiliation, his own being a form of Dutch Reformed Protestantism. Reading the interview, I was reminded of Edmund Gosse's (1925) account of growing up in a Plymouth Brethren environment in late nineteenth-century Britain. In the interview, van der Veer remarked, 'I have never been a believer'. At the age of eight, he had discovered that a belief in God or religion was 'not very plausible'. To some, it may seem somewhat too early (and hasty to boot)_losing something before acquiring it or exiting a zone ${ }^{16}$ before duly arriving there.

This critical evaluation of Peter van der Veer's diverse body of work published over the past three decades or so will, I hope, interest anthropologists, sociologists, scholars of comparative religions and politics, Indianists, Sinologists, Asianists and historians. In particular, it will interest Dutch sociologists and anthropologists. Scholars of academic biographies and intellectual historians, especially of Europe, may also find this chapter of some relevance. 


\section{Notes}

1. An earlier version of this chapter appeared in 2020 as a Working Paper published by the Max Planck Institute for the Study of Religious and Ethnic Diversity, Gottingen, Germany.

2. For an article in which he reviews works on Islam, see van der Veer (2004a).

3. The word 'mistress' connotes a secret relationship with pure enjoyment. Derrida seemed to think of philosophy 'as the unlimited jouissance of a thought that knows no empirical restraints' (Hage 2013: 79).

4. At Groningen van der Veer (1986: 343) studied Indo-Iranian languages (including Sanskrit) and cultures from 1973 to 1979. Jacob Ensink, who is acknowledged in Gods on Earth, taught Sanskrit there from 1951 to 1984. In 1953, he established the Institute of Indian Studies (dutchstudies-satsea.nl 2019). From 1980 to 1984, van der Veer lectured in 'Religious Anthropology' at the Free University of Amsterdam.

5. Trained in orientalism, Wael Hallaq (2018), a scholar of Islam currently at Columbia University, also criticized it to the extent that he found Edward Said wanting in recognizing the comprehensive constitution and effect of orientalism as an epistemic regime beyond the literary domains.

6. For collaborative works on Hinduism outside India, especially in the Caribbean and Surinam, see van der Veer and Cors van der Burg (1986) and van der Veer and Steve Vertovec (1991).

7. As Leiden University is deemed as the seat of orientalism, Kuitenbrouwer stresses van der Veer's identifications with the University of Amsterdam and his discipline, anthropology. There is also some rivalry between the two universities.

8. For references to Hurgronje in his other works in English, see van der Veer (2002b, 2004b) and van der Veer (2001b) in Dutch.

9. For a quasi-autobiographical account of his academic journey, see van der Veer (2008).

10. In 2018, the Arab Center for Research and Policy Studies, Qatar, published the Arabic edition (visually very attractive) of this book. See van der Veer and Lehmann (2018).

11. He is also deeply critical of experimental psychology and behaviourism in general, whose conclusion is based on a sample of Western, educated, industrialized, rich and democratic (WEIRD) societies—an evocative 
acronym (van der Veer 2016: 46). Through an excellent deconstruction of PEW surveys, he detects flaws in quantitative research, showing the richness of anthropological knowledge as an alternative.

12. Cf., Brigit Meyer's (2012) 'mentalistic approaches' and 'mentalism' in the studies of religion.

13. The omission of Clifford Geertz here is a bit surprising. His Islam Observed argued that, although both Indonesia and Morocco were mostly Muslim, they had contrasting holistic 'historical personages', 'character', and a 'national archetype'. See Ahmad (2018).

14. At Monash University, Australia, I supervised a doctoral thesis that aimed to explain comparatively why China left India behind in economic growth after 1947. The candidate, a Chinese national, explained it in terms of Hinduism and the caste system (oblivious, additionally, of the fact that about 20 per cent of India's population is not Hindu) and the charisma of Chairman Mao (as if India lacked charismatic leaders). She completed her thesis after I left Monash University.

15. On issues of cultural translation like incommensurability and isomorphism, see Ahmad (2019b).

16. The choice of the word 'zone' is intentional; van der Veer edited Routledge's book series titled 'Zones of Religion,' of which van der Veer (1996) is a part.

\section{References}

Ahmad, Irfan. 2013. In Defense of Ho(s)tel: Islamophobia, Domophilia and the West. Politics, Religion \& Ideology 14 (2): 234-252. Special Issue on 'Islamophobia, European Modernity and Contemporary Illiberalism'.

- 2015. On the State of the (Im)possible: Notes on Wael Hallaq's Thesis. Journal of Religious and Political Practice. 1 (1): 97-106.

2017. Religion as Critique: Islamic Critical Thinking from Mecca to the Marketplace. Chapel Hill: University of North Carolina Press.

- 2018. Twentieth-Century Faces of Anthropology's Holism. Anthropology News, May 18. https://anthrosource.onlinelibrary.wiley.com/ doi/10.1111/AN.868.

2019a. Populism: A
Anthropologist 1 (2): 224-245. 
- 2019b. Reply to Anidjar, Fernando, Lawrence and Moumtaz. Critical Research on Religion 7 (2): 1-9.

Ahmad, Irfan, and Pralay Kanungo. 2019. Preface. In The Algebra of Warfare Welfare: A Long View of India's 2014 Election, ed. Irfan Ahmad and Pralay Kanungo, xi-xvii. New Delhi: Oxford University Press.

Allen, Amy. 2016. The End of Progress: Decolonizing the Normative Foundations of Critical Theory. New York: Columbia University Press.

Allen, Kieran. 2017 [2004]. Weber: Sociologist of Empire. London: Pluto.

Appadurai, Arjun. 1996. Sovereignty without Territoriality: Notes for a Postnational Geography. In The Geography of Identity, ed. Patricia Yaeger, 40-58. Ann Arbor, MI: The University of Michigan Press.

Asad, Talal. 1987. Are there Histories of Peoples without Europe? A Review Article. Comparative Studies in Society and History. 29 (3): 594-607.

-1993. Genealogies of Religion: Discipline and Reason of Power in Christianity and Islam. Baltimore: Johns Hopkins University Press.

Braudel, Fernand. 1980. On History. Trans. Sarah Matthews. Chicago: The University of Chicago Press.

Breckenridge, Carol Appadurai, and Peter van der Veer. 1993. Introduction. In Orientalism and the Post-colonial Predicament: Perspectives on South Asia, ed. Carole Breckenridge and Peter van der Veer, 1-19. Philadelphia: University of Pennsylvania Press.

Brobjer, Thomas. 2010. To Philosophize with a Hammer: An Interpretation. Nietzsche-Studien. 28 (1): 38-41.

Chatterjee, Partha. 1986. Nationalist Thought and the Colonial World: A Derivative Discourse? London: Zed Books.

Cook, Deborah. 2018. Adorno, Foucault and the Critique of the West. London: Verso.

Cooper, Frederick. 2011. Alternatives to Nationalism in French West Africa, 1945-60. In Elites and Decolonization in the Twentieth Century, ed. Marc Frey and Jost Dülferr, 110-137. Basingstoke: Palgrave Macmillan.

Cooper, Fredrick. 2018. Federation, Confederation, Territorial State. In Forms of Pluralism and Democratic Constitutionalism, ed. Andrew Arato, Jean Cohen, and Astrid Von Busekist, 33-51. New York: Columbia University Press. Dumont, Louis. 1970. Religion, Politics and History in India: Collected Papers in Indian Sociology. The Hague: Mouton.

Dutchstudies-satsea.nl. 2019. Sanskrit Studies in Groningen: 1881-Present. https://www.dutchstudies-satsea.nl/sanskrit-studies-groningen/ (visited 21 May 2019). 
Farouk-Alli, Aslam. 2014. Sectarianism in Alawi Syria: Exploring the Paradoxes of Politics and Religion. Journal of Muslim Minority Affairs. 34 (3): 207-226. Fuller, Chris. 1994. Review of "Religious Nationalism". Man (New Series). 29 (4): 1024-1025.

Giddens, Anthony. 1990. The Consequences of Modernity. Stanford: Stanford University Press.

Goody, Jack. 2002. Elias and the Anthropological Tradition. Anthropological Theory. 2 (4): 401-412.

Gosse, Edmund. 1925 [1907]. Father and Son: A Study of Two Temperaments. London: Heinemann.

Hage, Ghassan. 2013. Eavesdropping on Bourdieu's Philosophers. Thesis Eleven. 114 (1): 76-93.

Hallaq, Wael. 2018. Restating Orientalism: A Critique of Modern Knowledge. New York: Columbia University Press.

Hasan, Mushirul. 1998. Aligarh's "Notre Eminent Contemporain”: Assessing Sayyid Ahmad Khan's Reformist Agenda. Economic and Political Weekly. 33 (19): 1077-1081.

Jaffrelot, Christophe. 1996. The Hindu Nationalist Movement and Indian Politics: 1925 to the 1990s: Strategies of Identity-Building, Implantation and Mobilization (with Special Reference to Central India). London: Hurst \& Co.

Kuitenbrouwer, Maarten. 2014. Dutch Scholarship in the Age of Empire and Beyond: KITLV, The Royal Netherlands Institute of Southeast Asian and Caribbean Studies, 1851-2011. Trans. Lorri Granger. Leiden, Boston: Brill. Kumar, Nita. 1990. Review of 'Gods on Earth': The Management of Religious Experience and Identity in a North Indian Pilgrimage Centre. American Ethnologist. 17 (3): 582-583.

Liston, Katie, and Stephen Mennell. 2009. Ill Met in Ghana: Jack Goody and Norbert Elias on Process and Progress in Africa. Theory, Culture \& Society. 26 (7-8): 52-70.

Ludden, David, ed. 1996. Making India Hindu: Religion, Community, and the Politics of Democracy in India. Philadelphia: University of Pennsylvania Press. Masuzawa, Tomoko. 2005. The Invention of World Religions: Or, How European Universalism Was Preserved in the Language of Pluralism. Chicago: The University of Chicago Press.

Matthews, David. 2018. Peter van der Veer: Academics Should Stop Ignoring Religion. Times Higher Education Supplement, August 23.

McKean, Lise. 1994. Review of "Religious Nationalism". Journal of Asian Studies. 53 (4): 1308-1309. 
Meyer, Brigit. 2012. Mediation and the Genesis of Presence: Towards a Material Approach to Religion. Lecture Delivered as Chair of Religious Studies, Faculty of Humanities, Utrecht University, The Netherlands.

Meyer, Birgit, and Peter van der Veer, eds. 2021. Refugees and Religion: Ethnographic Studies of Global Trajectories. New York: Bloomsbury Academic. Parekh, Bhikhu. 2019. Ethnocentric Political Theory: The Pursuit of Flawed Universals. Palgrave Macmillan.

Said, Edward. 1995 (1978). Orientalism. 2nd ed. London: Penguin.

Scott, David. 2006. The Trouble of Thinking: An Interview with Talal Asad. In Powers of the Secular Modern: Talal Asad and His Interlocutors, ed. David Scott and Charles Hirschkind, 243-303. Stanford: Stanford University Press.

Smith, Brian. 1997. Review of "Religious Nationalism". Journal of Church and State. 39 (1): 163-164.

Unichicago.edu. 2019, April 30. Acclaimed South Asian Visiting Scholar to Deliver Annual Vivekananda Lecture. https://humanities.uchicago.edu/articles/2019/04/acclaimed-south-asian-visiting-scholar-deliver-annualvivekananda-lecture.

van der Veer, Peter. 1985. Brahmans - Their Purity and Their Poverty: On the Changing Values of Brahman Priests in Ayodhya. Contributions to Indian Sociology (New Series). 19 (2): 303-321.

. 1986. Gods on Earth: The Management of Religious Experience and Identity in a North Indian Pilgrimage Centre. PhD Dissertation, Rijksuniversiteit te Utrecht, The Netherlands.

- 1987. Taming the Ascetic: Devotionalism in a Hindu Monastic Order. Man (New Series). 22: 680-695.

. 1988. Gods on Earth: The Management of Religious Experience and Identity in a North Indian Pilgrimage Centre. London School of Economics Monographs on Social Anthropology, 59. London: Athlone Press.

Studies. 51 (3): 545-564.

- 1993. The Foreign Hand: Orientalist Discourse in Sociology and Communalism. In Orientalism and the Post-colonial Predicament, ed. Carole Breckenridge and Peter van der Veer, 23-45. Philadelphia: University of Pennsylvania Press.

Berkeley: University of California Press. 
1994b. Hindu Nationalism and the Discourse of Modernity: The Vishwa Hindu Parishad. In Accounting for Fundamentalisms, ed. M. Marty and S. Appleby, 653-669. Chicago: University of Chicago Press.

- 1995. Modern oriëntalisme: essays over de westerse beschavingsdrang. Amsterdam: Meulenhoff.

—, ed. 1996. Conversion to Modernities: The Globalization of Christianity. London: Routledge.

- 2001a. Imperial Encounters: Religion, Nation, and Empire. Princeton: Princeton University Press.

- 2001b. Nederland en de islam. Amsterdams sociologisch tijdschrift. 28 (4): 513-524.

- 2002a [1995]. Islam en het 'beschaafde' Westen: Essays over de 'achterlijkheid'van religies. Amsterdam: Meulenhoff.

2002b. The Netherlands and Islam. ISIM Newsletter. 9 (2): 7-8.

. 2004a. South Asian Islam in Britain: Review Article. Ethnicities. 4 (2): $135-146$.

- 2004b. Cosmopolitan Options. In Worlds on the Move: Globalization, Migration and Cultural Security, ed. Jonathan Friedman and Shalini Randeria, 167-179. London: I.B. Tauris.

- 2006. Pim Fortuyn, Theo van Gogh, and the Politics of Tolerance in the Netherlands. Public Culture. 18 (1): 111-124.

- 2008. Religion, Secularism, and the Nation. India Review. 7 (4): 378-396.

- 2010. Comments on "Notes from a Small Place: Anthropological Blues in the Face of Global Terror" by Pnina Werbner. Current Anthropology. 51 (2): 215.

- 2011. Introduction. Encounters: An International Journal for the Study of Culture and Society 4 (2): 9-15. Special issue 'Religious Networks in Asia and Beyond', guest edited by Peter van der Veer.

- 2014. The Modern Spirit of Asia: The Spiritual and the Secular in China and India. Princeton: Princeton University Press.

- 2016. The Value of Comparison. Lewis Henry Morgan Lectures. Durham; London: Duke University Press.

van der Veer, Peter, and Hartmut Lehmann. 1999. Introduction. In Nation and Religion: Perspectives on Europe and Asia, ed. Peter van der Veer and Hartmut Lehmann, 3-13. Princeton University Press: Princeton.

- 2018. Al-Umma v din. Trans. Mahmoud Haddad and Saud al-Mouli) Qatar: Arab Center for Research and Policy Studies. 
der Veer, Van, and Peter. 1987. 'God Must Be Liberated!' A Hindu Liberation Movement in Ayodhya. Modern Asian Studies. 21 (2): 283-301. van der Veer, Peter, and Cors van der Burg. 1986. Pandits, Power and Profit:

Religious Organization and the Construction of Identity Among the Surinamese Hindus. Ethnic and Racial Studies. 9 (4): 514-528. van der Veer, Peter, and Steve Vertovec. 1991. Brahmanism Abroad: On Caribbean Hinduism as an Ethnic Religion. Ethnology. 30 (2): 149-166.

Open Access This chapter is licensed under the terms of the Creative Commons Attribution 4.0 International License (http://creativecommons.org/licenses/ by/4.0/), which permits use, sharing, adaptation, distribution and reproduction in any medium or format, as long as you give appropriate credit to the original author(s) and the source, provide a link to the Creative Commons licence and indicate if changes were made.

The images or other third party material in this chapter are included in the chapter's Creative Commons licence, unless indicated otherwise in a credit line to the material. If material is not included in the chapter's Creative Commons licence and your intended use is not permitted by statutory regulation or exceeds the permitted use, you will need to obtain permission directly from the copyright holder.

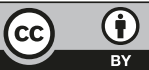

